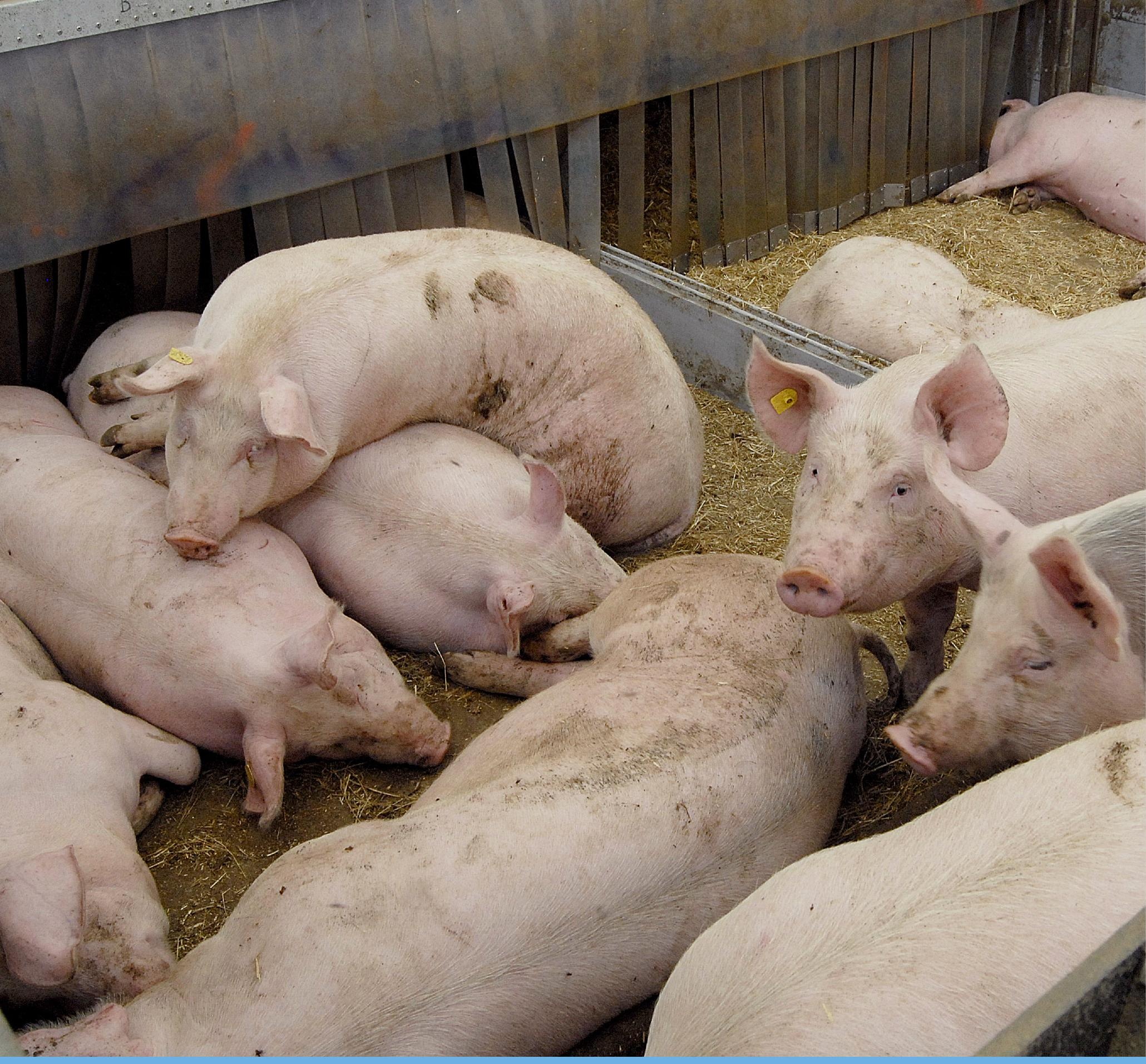

Fosforbenutting bij biologisch gehouden vleesvarkens

Paul Bikker, Naomi ten Tije, Achim Tijkorte

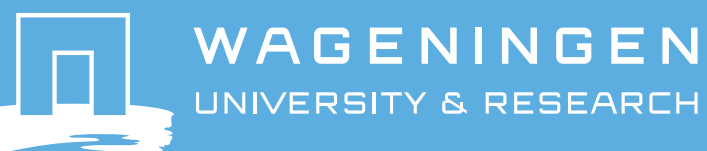





\section{Fosforbenutting bij biologisch gehouden vleesvarkens}

Praktijkonderzoek naar de mogelijke verlaging van het verteerbaar fosforgehalte in het rantsoen

Paul Bikker ${ }^{1}$, Naomi ten Tije ${ }^{2}$, Achim Tijkorte ${ }^{2}$

1 Wageningen Livestock Research

2 ForFarmers Reudink B.V.

Dit onderzoek is uitgevoerd door Wageningen Livestock Research, in opdracht van en medegefinancierd door het Ministerie van Economische Zaken, in het kader van de PPS "Vermindering fosforexcretie door biologisch gehouden varkens en pluimvee", via het Beleidsondersteunend onderzoekthema TKI-AF-BIO' (projectnummer BO-22.04-007-006)".

Wageningen Livestock Research

Wageningen, november 2017 
Bikker, P., N.G.M. ten Tije en A. Tijkorte, 2017. Fosforbenutting bij biologisch gehouden vleesvarkens; praktijkonderzoek naar de mogelijke verlaging van het verteerbaar fosforgehalte in het rantsoen. Wageningen Livestock Research, Rapport 1069.

\section{Samenvatting}

Dit rapport beschrijft een praktijkstudie naar de mogelijkheden om het verteerbaar fosfor (vP) gehalte in het rantsoen van biologisch gehouden vleesvarkens te verlagen. De verlaging van het berekend vPgehalte met $0,4 \mathrm{~g} / \mathrm{kg}$ ( $15 \%$ in startvoer, $20 \%$ in vleesvarkensvoer) had geen negatieve invloed op de gezondheid en groei van de varkens. Deze verlaging ten opzichte van het controlevoer draagt bij aan een hogere fosforbenutting. De gerealiseerde vP-gehalten, gebaseerd op analyse van voer en feces, waren echter aanzienlijk hoger dan vooraf berekend op basis van tabelwaarden. Hierdoor kan niet vastgesteld worden of een verlaging van het vP-gehalte ten opzichte van de norm voor regulier gehouden varkens mogelijk is zonder invloed op de dierprestaties.

\section{Summary}

An on-farm study was conducted into possibilities to reduce the digestible phosphorous (P) content in the diet of organic pigs. A reduction of $0.4 \mathrm{~g} / \mathrm{kg}$ ( $15 \%$ in the grower diet, $20 \%$ in the finisher diet) did not reduce growth performance and health of the pigs. The reduction contributes to a higher efficiency of $\mathrm{P}$ utilisation. However, the actual digestible $\mathrm{P}$ content of the diets, based on collection and analyses of feed and faeces was substantially higher than the calculated content based on table values. As a result, it was not possible to conclude whether the digestible P content can be reduced $15-20 \%$ below the current recommendations without compromising animal performance.

Dit rapport is gratis te downloaden op https://doi.org/10.18174/428030 of op www.wur.nl/livestock-research (onder Wageningen Livestock Research publicaties).

\section{(C) 2017 Wageningen Livestock Research}

Postbus 338, 6700 AH Wageningen, T 03174839 53, E info.livestockresearch@wur.nl, www.wur. nl/livestock-research. Wageningen Livestock Research is onderdeel van Wageningen University \& Research.

Wageningen Livestock Research aanvaardt geen aansprakelijkheid voor eventuele schade voortvloeiend uit het gebruik van de resultaten van dit onderzoek of de toepassing van de adviezen.

Alle rechten voorbehouden. Niets uit deze uitgave mag worden vermenigvuldigd en/of openbaar gemaakt worden door middel van druk, fotokopie, microfilm of op welke wijze dan ook zonder voorafgaande toestemming van de uitgever of auteur.

De certificering volgens ISO 9001 door DNV onderstreept ons kwaliteitsniveau. Op als onze onderzoeksopdrachten zijn de Algemene Voorwaarden van de Animal Sciences Group van toepassing. Deze zijn gedeponeerd bij de Arrondissementsrechtbank Zwolle. 


\section{Inhoud}

Woord vooraf $\quad 5$

$\begin{array}{ll}\text { Samenvatting } & 7\end{array}$

1

$\begin{array}{ll}\text { Inleiding } & 9\end{array}$

1.1 Achtergrond $\quad 9$

1.2 Verlagen fosforexcretie 9

$\begin{array}{lll}1.3 & \text { Doel } & 10\end{array}$

2

Materiaal en methode $\quad 11$

$\begin{array}{lll}2.1 & \text { Proeflocatie en proefdieren } & 11\end{array}$

2.2 Proefopzet en behandelingen 11

$\begin{array}{lll}2.3 & \text { Proefvoeders en voedering } & 11\end{array}$

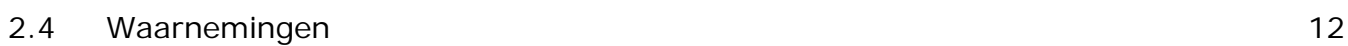

2.4.1 Groeiprestaties $\quad 12$

2.4.2 Karkas- en botkwaliteit $\quad 12$

$\begin{array}{ll}2.4 .3 \text { Vertering } & 12\end{array}$

2.4.4 Urine 12

2.4.5 Bloed 12

2.5 Chemische analyses 13

$\begin{array}{lll}2.6 & \text { Berekening en statistische analyse } & 13\end{array}$

$3 \quad$ Resultaten en discussie $r$

$\begin{array}{lll}3.1 & \text { Verloop van de proef } & 14\end{array}$

$\begin{array}{lll}3.2 & \text { Voersamenstelling } & 14\end{array}$

$\begin{array}{lll}3.3 & \text { Groeiprestaties } & 14\end{array}$

$\begin{array}{lll}3.4 & \text { Vertering } & 15\end{array}$

$\begin{array}{lll}3.5 & \text { Excretie in de urine } & 16\end{array}$

$\begin{array}{lll}3.6 & \text { Bloedspiegels } & 17\end{array}$

$\begin{array}{lll}3.7 & \text { Botkenmerken } & 17\end{array}$

$\begin{array}{lll}3.8 & \text { Algemene discussie } & 18\end{array}$

4

$\begin{array}{ll}\text { Conclusies } & 20\end{array}$

$\begin{array}{ll}\text { Literatuur } & \mathbf{2 1}\end{array}$

Bijlage 1 Gehanteerde voerschema's $\quad 22$ 



\section{Woord vooraf}

Dit rapport is een weergave van een praktijkproef waarin werd nagegaan of het gehalte aan verteerbaar fosfor in het rantsoen van vleesvarkens verlaagd kan worden ten opzichte van de gangbare aanbevelingen, zonder negatieve effecten op groeiprestaties of diergezondheid. Deze studie is onderdeel van het PPS-project "Vermindering fosforexcretie door biologisch gehouden varkens en pluimvee" uitgevoerd in opdracht van het Ministerie van Economische Zaken in samenwerking met een aantal private partners. Omdat in de biologische varkenshouderij het gebruik van microbieel fytase niet is toegelaten zijn andere maatregelen nodig om de fosforbenutting te verhogen. Doel van dit project is de fosforefficiëntie bij biologisch gehouden varkens en pluimvee te verbeteren met als gevolg een lagere mineralenuitstoot en een verruiming van de plaatsingsmogelijkheden van biologische varkensmest en pluimveemest. Het hier beschreven praktijkonderzoek is uitgevoerd in samenwerking tussen Wageningen Livestock Research en ForFarmers Reudink op het biologisch varkensbedrijf van Mts. Van den Bogert-Hoeflaken te Hedel. De begeleiding van de uitvoering en verwerking van de waarnemingen was in handen van Naomi ten Tije als onderdeel van een stage en afstudeerproject in het kader van haar studie aan de Aeres Hogeschool Dronten. We danken alle betrokkenen voor hun enthousiaste en deskundige medewerking aan deze studie.

Marinus van Krimpen, projectleider 


\section{Samenvatting}

Deze praktijkstudie is uitgevoerd om na te gaan of het verteerbaar fosfor (vP) gehalte in het rantsoen voor biologisch gehouden groeiende varkens ten opzichte van de gangbare norm verlaagd kan worden zonder dat dit ten koste gaat van de groeiprestaties en de diergezondheid. Er werd hiervoor een proef uitgevoerd met 2 proefbehandelingen bij biologisch gehouden vleesvarkens. De behandelingen waren i) een controlerantsoen met een berekend vP-gehalte gebaseerd op de normen voor regulier gehouden varkens en ii) een rantsoen waarin het vP-gehalte met $0,4 \mathrm{~g} / \mathrm{kg}$ (respectievelijk 15 en $20 \%$ ) was verlaagd in de start en vleesvarkensfase. De rantsoenen bestonden voor ca. 1/3 uit een granenmengsel en 2/3 aanvullend start- en vleesvarkensvoer. Het contrast werd aangelegd door aan het granenmengsel wel of geen monocalciumfosfaat toe te voegen. Beide behandelingen werden uitgevoerd met 2 proefgroepen met 55 vleesvarkens van circa 25 tot $120 \mathrm{~kg}$. De groeiprestaties en slachtkwaliteit werden geregistreerd voor alle dieren. Daarnaast werd bij een selectie van dieren de verteerbaarheid van de rantsoenen, de excretie van calcium en fosfor in de urine en het gewicht en asgehalte van de metacarpus 3 en 4, botjes in de voorpoot, bepaald.

- De varkens werden gemiddeld na 119 dagen afgeleverd bij een gewicht van $121 \mathrm{~kg}$, met een gemiddelde voeropname van $2,40 \mathrm{~kg} / \mathrm{d}$, een groei van $805 \mathrm{~g} / \mathrm{d}$ en een voederconversie van 3,02. De verlaging van het vP-gehalte had geen invloed op de gezondheid, groeiprestaties en de karkaskwaliteit van de varkens. Een verlaging ten opzichte van het in deze proef gebruikte controlerantsoen kan dus probleemloos worden toegepast.

- $\quad$ De verlaging van het vP-gehalte resulteerde in een geringe daling (niet-significant) van de botmineralisatie en hiermee samenhangend een iets hoger Ca-gehalte in de urine. Dit komt overeen met de verwachting omdat omgekeerd is aangetoond dat een hoger fosforgehalte in het voer, ook boven de behoefte voor maximale groei, resulteert in een hogere botmineralisatie.

- De gerealiseerde vP-gehalten, gebaseerd op analyses van voer en mest (feces), in het controlerantsoen en het rantsoen met verlaagd vP-gehalte waren beide aanmerkelijk hoger dan vooraf was berekend op basis van tabelwaarden voor de verteerbaarheid van P. Als gevolg hiervan kan geen uitspraak gedaan worden over de consequenties van een verlaging van het vPgehalte tot 15 à $20 \%$ onder de norm voor reguliere varkens.

- $\quad$ Meer inzicht en een betere inschatting van het vP-gehalte van de voeders, inclusief het effect van aanwezig intrinsiek fytase kan de kans op over- of onder dosering van vP verminderen en bijdragen aan het gerichter op de vP-norm voeren van de varkens en een efficiëntere P-benutting. 


\section{Inleiding}

\subsection{Achtergrond}

In verband met het streven naar evenwichtsbemesting zijn de fosfaatgebruiksnormen $\left(\mathrm{P}_{2} \mathrm{O}_{5}\right)$ van cultuurgrond de afgelopen jaren geleidelijk verlaagd. Op dit moment bepaalt het fosfaatgehalte in de mest veelal de hoeveelheid biologische varkens- en pluimveemest die per hectare aangewend mag worden en daarmee ook de plaatsingsruimte voor biologische mest. Voor de biologische akkerbouwer vormen de fosfaatgebruiksnormen een beperkende factor omdat wanneer de maximale hoeveelheid fosfaat is aangevoerd, er nog steeds ruimte en behoefte is om stikstof $(N)$ uit organische mest aan te voeren. Een stikstof/fosfaat verhouding in mest van circa 3:1 is voor veel gewassen gewenst, terwijl deze verhouding in biologische varkens- en pluimveemest rond de 1-1.5: 1 ligt (Nauta en Staps, 2011; Prins en De Buisonjé, 2014). Dit heeft tot gevolg dat de aanwendingsruimte voor $\mathrm{N}$ in de biologische akkerbouw niet optimaal kan worden benut en versterkt de noodzaak tot export van biologische mest van varkens- en/of pluimvee. Door de sterke groei van met name de biologische legpluimveehouderij en de grootschalige import van voedermiddelen is er meer aanbod van biologische varkens- en pluimveemest dan vraag in de biologische akkerbouw wat leidt tot een overschot van biologische mest in Nederland. Op dit moment wordt 60-70\% van de pluimveemest geëxporteerd, wat de biologische veehouderij afhankelijk maakt van mestexport en de kosten van mestafzet verhoogt (Nauta en Staps, 2011). De excretie van $N$ en fosfor $(P)$ via de mest is bij biologisch gehouden varkens en pluimvee hoger dan bij gangbaar gehouden dieren. Bikker et al. (2013a) berekenden dat de P-excretie van biologisch gehouden vleesvarkens en zeugen respectievelijk circa 25 en $75 \%$ hoger is dan van gangbaar gehouden dieren. Deze verschillen worden met name veroorzaakt door een hoger voerverbruik, een hogere voederconversie en een hoger P-gehalte in het voer van biologisch gehouden dieren. Het hoger P-gehalte hangt samen met het feit dat microbieel fytase, een enzym dat fytaat afbreekt en de P-verteerbaarheid verhoogt, niet toegevoegd mag worden aan biologische voeders. Hierdoor is een hoger totaal P-gehalte nodig om een vergelijkbaar vP-gehalte als in regulier voer te realiseren. De stikstof $(\mathrm{N})$ excretie van biologisch gehouden dieren is hoger dan van gangbaar gehouden dieren, met name vanwege de hogere voederconversie en omdat geen gebruik gemaakt mag worden van zuivere aminozuren, waardoor biologische voeders een hoger ruw eiwitgehalte hebben.

\subsection{Verlagen fosforexcretie}

Om fosforbenutting van groeiende varkens en zeugen te verbeteren en de excretie te verminderen moet de fosforopname via het voer worden verlaagd door een hogere fosforverteerbaarheid te realiseren en door de dieren zo nauwkeurig mogelijk naar hun fosforbehoefte te voeren. In de gangbare varkenshouderij kan een betere verteerbaarheid gerealiseerd worden door het toevoegen van microbieel fytase aan de voeders. Daarnaast kan een gerichte keuze van voedermiddelen bijdragen aan een hogere P-verteerbaarheid. Door de relatief grote vraag naar biologische voedermiddelen ten opzichte van de beperkte beschikbaarheid hiervan en de grote afhankelijkheid van import van voedermiddelen (Früh et al., 2015) zijn de mogelijkheden om specifiek voedermiddelen met een hoge P-verteerbaarheid te selecteren beperkt. Bij het nauwkeuriger voeren naar $\mathrm{P}$ behoefte wordt voorkomen dat aan de dieren te veel $\mathrm{P}$ wordt verstrekt, maar daarbij moet worden voorkomen dat de dieren te weinig $\mathrm{P}$ krijgen. Dit kan nadelig zijn voor de groei en botsterkte van de varkens (Bikker et al., 2013b). Bij de productie van biologische voeders wordt het fosforgehalte veelal gebaseerd op dezelfde normen als voor regulier gehouden varkens. Deze normen zijn gebaseerd op een relatief hoge botmineralisatie, maar bij vleesvarkens is maximale botmineralisatie niet noodzakelijk (Jongbloed et al., 2003). De voederconversie van biologisch gehouden vleesvarkens is gemiddeld hoger dan van regulier gehouden varkens, onder andere omdat meer energie wordt gebruikt voor beweging en thermoregulatie vanwege de grotere bewegingsruimte en de buitenuitloop (Bikker et al., 2013a). Hierdoor krijgen biologisch gehouden dieren bij een gelijk P-gehalte in het voer 
een hoger $\mathrm{P}$ aanbod per $\mathrm{kg}$ lichaamsgroei. Eerder is aangetoond dat dit de mogelijkheid biedt het aminozurengehalte per EW te verlagen zonder dat dit ten koste gaat van de groeiprestaties (Van der Peet-Schwering et al., 2009). Daarnaast draagt beweging bij aan een hogere botsterkte zoals aangetoond bij groepsgehuisveste zeugen ten opzichte van individueel gehuisveste zeugen (Marchant and Broom, 1996). Deze factoren dragen naar verwachting bij aan de mogelijkheid het verteerbaar Pgehalte in het voer van vleesvarkens te verlagen zonder dat dit ten koste gaat van groei en kwaliteit van het beenwerk. Onze hypothese was dan ook dat het verteerbaar P-gehalte in voer voor vleesvarkens verlaagd kan worden ten opzichte van de huidige normering zonder dat dit ten koste gaat van groei en gezondheid van de dieren.

\subsection{Doel}

Het doel van dit onderzoek was na te gaan of het verteerbaar P-gehalte in voer voor vleesvarkens verlaagd kan worden ten opzichte van de huidige normering zonder dat dit ten koste gaat van groei en kwaliteit van het beenwerk. 


\section{Materiaal en methode}

\subsection{Proeflocatie en proefdieren}

De proef is uitgevoerd op een biologisch varkensbedrijf met 130 fokzeugen en 800-900 vleesvarkens. Dit bedrijf houdt sinds 2004 biologische varkens en is SKAL-gecertificeerd. De biologische vleesvarkens hadden de beschikking over ruime stallen met een strobed en een verharde uitloop naar buiten. Wekelijks werd een groep van circa 55 biggen gespeend en in één hok in de biggenstal opgelegd. Op een leeftijd van 77 dagen werd deze groep dieren overgeplaatst naar een vleesvarkenshok. Dit betekende dat de proef met herhalingen in de tijd moest worden uitgevoerd, waarbij tegelijkertijd één proefgroep van beide behandelingen, met een week leeftijdverschil, kon worden opgelegd. De proef is uitgevoerd met twee herhalingen (hokken) per behandeling. Een groep bestond uit 55 gemengd gehuisveste vleesvarkens, zeugen en borgen, van een Pietrain $\times$ Topigs 20 kruising. Daarnaast was er een kleine aantal Topigs 20 borgen als bijproduct van de productie van de zeugenlijn. De varkens waren gehuisvest in hokken van circa 15,4 $\mathrm{m}$ diep en 4,7 m breed, met een verharde uitloop van $10,7 \times 4,7 \mathrm{~m}$.

\subsection{Proefopzet en behandelingen}

De proef omvatte twee behandelingen: een controlebehandeling waarvoor het (schijnbaar) vP-gehalte volgens de normen van Jongbloed et al. (2003) en Bikker and Blok (2017) was berekend en een behandeling waarin het vP-gehalte met $0,4 \mathrm{~g} / \mathrm{kg}$ ( $15 \%$ in startvoer, $20 \%$ in vleesvarkensvoer) was verlaagd. Deze verlaging was gebaseerd op een verschil in gemiddelde EW-conversie tussen reguliere en biologische bedrijven van circa 0.3 punten (EW-conversie 2.9 versus 3.2 ). De fosforgehalten in de voeders (met ca. 1,05 EW/ kg, tabel 1) waren per behandeling:

1. Controle, startvoer met $2,6 \mathrm{~g} \mathrm{vP} / \mathrm{kg}$ en vleesvarkensvoer met $1,9 \mathrm{~g} \mathrm{vP} / \mathrm{kg}$.

2. Laag fosfor, startvoer met $2,2 \mathrm{~g} \mathrm{vP} / \mathrm{kg}$ en vleesvarkensvoer met $1,5 \mathrm{~g} \mathrm{vP} / \mathrm{kg}$.

Het Ca-gehalte werd evenredig aan het vP gehalte verlaagd door verlaging van het aandeel monocalciumfosfaat in het rantsoen (zie paragraaf 2.3 ).

Elke behandeling werd uitgevoerd bij 2 groepen van 55 dieren, vanaf opleggen in de vleesvarkensstal bij een leeftijd van ca. 77 dagen tot slachten bij een gewicht van circa $120 \mathrm{~kg}$. De dieren kregen vanaf opleggen 6 weken startvoer, 2 weken tussenvoer (een mengsel van startvoer en vleesvarkensvoer) en aansluitend volledig vleesvarkensvoer.

\subsection{Proefvoeders en voedering}

Het rantsoen bestond in beide behandelingen uit 67-68,5\% mengvoer (startvoer en vleesvarkensvoer) met een laag P-gehalte en 31,5-33\% van een granenmengsel met 50\% tarwe, $25 \%$ rogge en $25 \%$ tarwegries met of zonder toegevoegd $\mathrm{P}$ en $\mathrm{Ca}$. Varkens van de controlegroep kregen het granenmengsel met toegevoegd $\mathrm{P}$, de dieren van de laag $\mathrm{P}$-groep kregen het granenmengsel zonder toegevoegd $\mathrm{P}$. Het mengvoer en het granenmengsel zonder toegevoegd $\mathrm{P}$ werden door Reudink geleverd conform de vereiste specificaties. Het granenmengsel met hoog $\mathrm{P}$ werd op het bedrijf zelf gemengd door toevoegen van $0.75 \%$ monocalciumfosfaat $(0,24 \%$ per $\mathrm{kg}$ compleet rantsoen). Het granenmengsel zonder toegevoegd $\mathrm{P}$ bestond uit dezelfde verhouding aan graan en tarwegries als het hoog P mengsel. De mengsels bestonden echter niet uit dezelfde levering granen. De mengverhouding van de rantsoenen is weergegeven in bijlage 1 . Deze zijn door de varkenshouder in de voercomputer gezet en door Reudink gecontroleerd om vergissingen uit te sluiten. Tijdens de proef werden op verschillende momenten voermonsters genomen om de samenstelling van het voer te controleren. 
Tot een gewicht van 80 á 90 kilo werden de varkens onbeperkt gevoerd, hierna werd de voergift beperkt tot $2,86 \mathrm{~kg}$ per varken per dag om vervetting te voorkomen. In principe konden de varkens hier de hele dag van eten en was het voer circa een uur voor de volgende voergift op. Het voer werd verstrekt om 7 uur 's morgens en om half 6 's middags.

\subsection{Waarnemingen}

Tijdens uitvoering van de proef vonden een aantal waarnemingen en bepalingen plaats. Dit betrof de voeropname, het gewicht van de dieren en karkaskenmerken bij slachten. Daarnaast werden op enkele momenten bij een selectie van dieren bloed, mest (feces) en urine verzameld en werd na slachten een voorpoot geanalyseerd voor de bepaling van de botkwaliteit.

\subsubsection{Voeropname, gewicht en groeiprestaties}

Wekelijks werd op maandagmiddag de verstrekte hoeveelheid voer per hok vanuit de voercomputer geregistreerd. De dieren werden individueel gewogen bij opleggen als vleesvarkens op een leeftijd van circa 77 dagen, bij de overgang van startvoer naar vleesvarkensvoer ( 6 weken na opleggen), bij de eerste keer afleveren (circa 14 weken na opleggen) en bij afleveren van de resterende dieren.

\subsubsection{Karkas- en botkwaliteit}

$\mathrm{Na}$ de eindweging werden de dieren van een slachtblik voorzien en werd een koppeling gelegd tussen het diernummer en slachtbliknummer om de karkaskwaliteit en eventuele afwijkingen bij slachten aan de proefbehandelingen te kunnen relateren. Bij slachten werd het karkasgewicht, de spier- en spekdikte en het vleespercentage bepaald en werden eventuele afwijkingen vastgelegd. Daarnaast werd bij 8 aselect gekozen dieren per groep, geslacht in de tweede week van afleveren, de rechter voorpoot verzameld en ingevroren. Na afloop van de proef werden de metacarpus 3 en 4 hieruit vrijgeprepareerd en werd hierin het as-gehalte bepaald als indicator van de botsterkte.

\subsubsection{Vertering}

Om de verteerbaarheid van het voer en de excretie te bepalen is gedurende twee perioden mest (feces) verzameld: in de startperiode, 2 weken na opleggen, en in de vleesvarkensperiode, 13 weken na opleggen bij de eerste twee herhalingen en 11 weken na opleggen bij de laatste twee herhalingen. De verse mest werd gedurende 2 achtereenvolgende dagen tweemaal daags bij minimaal 8 willekeurige dieren per groep verzameld. De monsters werden gelabeld, gekoeld opgeslagen, gepoold per hok per dag en ingevroren $\left(-20^{\circ} \mathrm{C}\right)$ tot uitvoering van de analyses. Aan het vleesvarkensvoer werd 5 dagen voorafgaand aan de mestverzameling $3 \%$ diamol als indicator toegevoegd. In de startvoerperiode was het niet mogelijk dit tijdig te realiseren en werd van de natuurlijk aanwezige $\mathrm{HCl}$-onoplosbare as in het voer als indicator gebruik gemaakt. In de mest zijn drogestof, ruw eiwit, ruw as, $\mathrm{HCl}$-onoplosbare as, $\mathrm{P}$, en Ca geanalyseerd.

\subsubsection{Urine}

Om na te gaan of de P-verlaging een invloed had op de P-excretie in de urine is gedurende twee perioden urine verzameld: in de startperiode, 2 weken na opleggen, en in de vleesvarkensperiode, 10 weken na opleggen. De verse urine werd gedurende 2 achtereenvolgende dagen tweemaal daags bij minimaal 8 willekeurige dieren per groep verzameld. Per verzamelmoment werd de urine van 4 dieren samengevoegd en ingevroren $\left(-20^{\circ} \mathrm{C}\right)$ bewaard tot analyse. In de urine zijn de gehalten aan $\mathrm{P}, \mathrm{Ca}$ en creatinine geanalyseerd.

\subsubsection{Bloed}

Om de gezondheid van de dieren te bewaken is door de dierenarts tweemaal bij 8 dieren per groep een bloedmonster afgenomen. Dit vond plaats in de startvoerperiode, in de $3^{e}$ week na opleggen bij de eerste twee herhalingen en in de $4^{\mathrm{e}}$ week na opleggen bij de laatste twee herhalingen, en in de 
vleesvarkensperiode, 11 weken na opleggen, bij alle groepen. Bloedafname vond plaats tussen 9.00 en 10.00 uur 's morgens. Twee uur na afname zijn de bloedmonsters afgedraaid bij $2000 \mathrm{~g}$ (4400 rpm) gedurende 10 minuten in een Hettich centrifuge, waarna serum bij $-32^{\circ} \mathrm{C}$ is ingevroren tot analyse. In het serum is het gehalte aan $\mathrm{Ca}$ en anorganisch $\mathrm{P}$ bepaald.

\subsection{Chemische analyses}

Voermonsters werden gemalen over een $1 \mathrm{~mm}$ zeef en geanalyseerd op vocht (droge stof), anorganische stof (as), $\mathrm{HCl}$-onoplosbare as, ruw eiwit (RE), $\mathrm{Ca}$, en $\mathrm{P}$. Droge stof werd bepaald door het drogen bij $103^{\circ} \mathrm{C}$ tot een constant gewicht (ISO, 6496). Ruw eiwit werd berekend als $\mathrm{N} \times 6,25 \mathrm{na}$ analyse van $\mathrm{N}$ met de Kjeldahl methode met CuSO4 als katalysator (ISO 5983). Ruwe as werd bepaald door verassing bij $550^{\circ} \mathrm{C}$ tot een constant gewicht (ISO, 5984). Calcium en $\mathrm{P}$ werden bepaald na verassing bij $550^{\circ} \mathrm{C}$, oplossen van het residu in $\mathrm{HCl}$ en analyse met ICP AES (Perkin Elmer Optima 7300 DV) (NEN-EN 15510: 2007). Daarnaast werd het P-gehalte in voeders tijdens de proef gecontroleerd middels spectrofotometrie (ISO 6491). Mestmonsters werden na vriesdrogen op vergelijkbare wijze gemalen en geanalyseerd op vocht, as, $\mathrm{HCl}$-onoplosbare as, $\mathrm{Ca}$ en $\mathrm{P}$. Urine monsters werden fotometrisch geanalyseerd op Ca, $\mathrm{P}$ en creatinine met een Cobas 8000 analyser voor klinische analyses met een C701 Photometric measuring unit (Roche Diagnostics Limited, Rotkreuz, Switzerland). Gehalte aan calcium en anorganisch P in serum werd eveneens fotometrisch bepaald. De metacarpus 3 en 4 botjes werden na weken in warm water ontdaan van spier- en bindweefsel en gebroken, waarna het vet werd geëxtraheerd met petroleum (kookpunt 40-60 ${ }^{\circ} \mathrm{C}$ ) (ISO, 6492). Aansluitend werden de botjes gedroogd bij $103^{\circ} \mathrm{C}$ tot een constant gewicht $($ ISO, 6496) en verast bij $850^{\circ} \mathrm{C}$ tot een constant gewicht gedurende zes uur (ISO, 5984). Op basis van de resultaten werd het asgehalte in de vetvrije drogestof bepaald.

\subsection{Berekening en statistische analyse}

De verteringscoëfficiënten (VC) van DS, AS, organische stof (OS), Ca en P werden berekend met $\mathrm{HCl}$ onoplosbare as als marker met behulp van de volgende formule:

$\operatorname{VC}(\%)=100-\left[100 \times\left(\right.\right.$ marker $_{\text {voer }} \times$ nutrient $\left._{\text {mest }}\right) /\left(\right.$ marker $_{\text {mest }} \times$ nutrient $\left.\left._{\text {voer }}\right)\right]$

met marker voer $_{\text {en }}$ markermest als geanalyseerde gehalten aan $\mathrm{HCl}$-as in voer en mest, en nutriëntvoer en nutriënt $t_{\text {mest }}$ als de geanalyseerde gehalten aan de bovengenoemde nutriënten in voer en mest. Het vP gehalte $(\mathrm{g} / \mathrm{kg})$ werd berekend als P-gehalte $(\mathrm{g} / \mathrm{kg}) \times$ verteringscoëfficiënt $(\%) / 100$

De gegevens van de proef zijn opgeslagen en verwerkt in Excel. De resultaten zijn statistisch geanalyseerd met variantieanalyse (ANOVA) in het statistisch programma Genstat met hok als de experimentele eenheid. De data zijn geanalyseerd met proefbehandeling als verklarende variabele (fixed factor). Bij kenmerken die zowel in de startvoerfase als de vleesvarkensfase zijn vastgesteld (vertering, Ca en $\mathrm{P}$ in urine en bloed) werd ook het effect van de periode en de interactie met de proefbehandeling bepaald. Een P-waarde $<0.05$ werd beschouwd als significant, $\mathrm{P}<0.1$ als een trend. 


\section{Resultaten en discussie}

\subsection{Verloop van de proef}

De proef verliep grotendeels volgens planning. In de $4^{\mathrm{e}}$ week moest een achterblijver uit de laatste herhaling (controlegroep) worden verwijderd. Na 13 weken werd bij een zestal dieren uit de eerste herhaling (controlegroep) een ontsteking geconstateerd die wellicht het gevolg was van staartbijten in deze groep. De betreffende 6 dieren zijn uit de groep verwijderd; bij de berekening van de groei en voederconversie is hiermee rekening gehouden.

\subsection{Voersamenstelling}

In tabel 1 zijn de berekende en gerealiseerde voersamenstelling weergegeven. In het algemeen kwamen de geanalyseerde nutriëntgehalten goed overeen met de vooraf berekende waarden. Het Cagehalte in de startvoeders was circa $1 \mathrm{~g} / \mathrm{kg}$ hoger dan vooraf berekend, wellicht door een hoger Cagehalte ten opzichte van de tabelwaarde in een of meer van de gebruikte grondstoffen. Het P-gehalte was in alle voeders iets hoger dan vooraf berekend op basis van de gebruikte grondstoffen, maar het verschil tussen controlevoer en voer met verlaagd vP-gehalte kwam goed overeen met de verwachting.

Tabel 1 Berekende en geanalyseerde nutriëntgehalten in proefrantsoenen met een controle en verlaagd verteerbaar fosfor ( $\mathrm{VP}$ ) gehalte, verstrekt aan biologisch gehouden vleesvarkens tot een levend gewicht van ca. $120 \mathrm{~kg}$.

\begin{tabular}{|c|c|c|c|c|}
\hline Kenmerk & $\begin{array}{l}\text { Startvoer } \\
\text { CON }\end{array}$ & $\begin{array}{l}\text { Startvoer } \\
\text { Laag P }\end{array}$ & $\begin{array}{c}\text { Vleesvarkensvoer } \\
\text { CON }\end{array}$ & $\begin{array}{c}\text { Vleesvarkensvoer } \\
\text { Laag P }\end{array}$ \\
\hline \multicolumn{5}{|l|}{ Berekend } \\
\hline Energiewaarde, EW & 1,07 & 1,06 & 1,05 & 1,04 \\
\hline Ruw eiwit, g/kg & 179 & 180 & 161 & 163 \\
\hline Anorganische stof, $\mathrm{g} / \mathrm{kg}$ & 52,6 & 51,2 & 46,5 & 44,5 \\
\hline Fosfor $(P), g / k g$ & 5,35 & 5,04 & 4,85 & 4,55 \\
\hline $\mathrm{VP}(\mathrm{VC}, \%)^{1)}$ & $2,60(48,6 \%)$ & $2,20(43,6 \%)$ & $1,88(38,8 \%)$ & $1,50(32,9 \%)$ \\
\hline Calcium, g/kg & 7,51 & 6,97 & 6,03 & 5,50 \\
\hline \multicolumn{5}{|l|}{ Geanalyseerd $^{2)}$} \\
\hline Ruw eiwit, g/kg & $181(176 ; 176)$ & $176(181 ; 185)$ & $164(160)$ & 165 (167) \\
\hline Anorganische stof, $\mathrm{g} / \mathrm{kg}$ & 53 & 50 & $66^{3)}$ & $60^{3)}$ \\
\hline $\mathrm{HCl}$-onoplosbare as & 5,8 & 5,7 & $21,5^{3)}$ & $19,1^{3)}$ \\
\hline Fosfor, $\mathrm{g} / \mathrm{kg}$ & $5,56(5,4 ; 5,4)$ & $5,14(4,9 ; 4,9)$ & 5,2 & 4,9 \\
\hline Calcium, $\mathrm{g} / \mathrm{kg}$ & 8,62 & 8,02 & 5,78 & 5,28 \\
\hline Fytase, FTU/kg & 251 & 288 & 281 & 225 \\
\hline \multicolumn{5}{|c|}{$\begin{array}{l}\text { 2) Bepaald in de perioden van mestverzamelen voor het berekenen van de verteerbaarheid. Waarden tussen haakjes zijn } \\
\text { tussentijds ter controle bepaald. }\end{array}$} \\
\hline
\end{tabular}

\subsection{Groeiprestaties}

De groeiprestaties van de varkens zijn weergegeven in Tabel 2. Na circa 100 dagen werden de eerste varkens afgeleverd. Hieraan voorafgaand werden alle dieren gewogen. De varkens werden gemiddeld 
na 119 dagen afgeleverd bij een gewicht van $121 \mathrm{~kg}$, met een gemiddelde voeropname van 2,40 kg/d, een groei van $805 \mathrm{~g} / \mathrm{d}$ en een voederconversie van 3.02. De verlaging van het vP-gehalte had geen invloed op de groeiprestaties en de karkaskwaliteit.

Tabel 2 Invloed van een verlaging van het verteerbaar fosfor (vP) gehalte in het voer met 15\% op de groeiprestaties van biologisch gehouden vleesvarkens van opleg tot afleveren.

\begin{tabular}{lcccc} 
Kenmerk & Controle & Laag P & SEM & P-waarde \\
Startperiode & 2 hokken & 2 hokken & & \\
\hline Opleggewicht, $\mathrm{kg}$ & 25,5 & 26,0 & 1,7 & 0,839 \\
\hline Lengte, d & 42 & 42 & - & - \\
\hline Voeropname, kg/d & 1,75 & 1,81 & 0,12 & 0,764 \\
\hline Groei, g/d & 711 & 718 & 31 & 0,887 \\
\hline Voederconversie & 2,47 & 2,52 & 0,08 & 0,682 \\
\hline Overgangsgewicht, $\mathrm{kg}$ & 55,3 & 56,2 & 2,89 & 0,853 \\
\hline
\end{tabular}

\section{Vleesvarkensperiode tot $1^{\mathrm{e}}$ levering}

\begin{tabular}{lcccc}
\hline Lengte, $d$ & 58 & 61 & 6,4 & 0,769 \\
\hline Voeropname, $\mathrm{kg} / \mathrm{d}$ & 2,68 & 2,72 & 0,017 & 0,266 \\
\hline Groei, g/d & $862(841)^{1}$ & 845 & 26 & 0,679 \\
\hline Voederconversie & $3,11(3,18)^{1}$ & 3,22 & 0,11 & 0,541 \\
\hline Gewicht bij $1^{\mathrm{e}}$ aflevering, $\mathrm{kg}$ & 105,2 & 107,8 & 2,65 & 0,553 \\
\hline
\end{tabular}

\section{Gehele groeitraject (opleg tot $1^{\mathrm{e}}$ levering)}

\begin{tabular}{lcccc}
\hline Lengte, $d$ & 100 & 103 & 6,3 & 0,769 \\
\hline Voeropname, kg/d & 2,28 & 2,35 & 0,042 & 0,400 \\
\hline Groei, g/d & $799(787)^{1}$ & 794 & 18 & 0,856 \\
\hline Voederconversie & $2,86(2.90)^{1}$ & 2,96 & 0,09 & 0,511 \\
\hline
\end{tabular}

\begin{tabular}{|c|c|c|c|c|}
\hline \multicolumn{5}{|c|}{ Vleesvarkenperiode tot afleveren } \\
\hline Lengte, $d$ & 77.3 & 77.3 & 2.9 & 0.987 \\
\hline Voeropname, kg/d & 2.72 & 2.74 & 0.016 & 0.577 \\
\hline Voederconversie & 3.21 & 3.31 & 0.09 & 0.525 \\
\hline Gewicht bij aflevering, kg & 121.5 & 120.7 & 1.00 & 0.624 \\
\hline
\end{tabular}

\section{Groeitraject tot afleveren}

\begin{tabular}{lcccc} 
Groeitraject tot afleveren & 119 & 119 & 2.9 & 0.987 \\
\hline Lengte, d & 2.38 & 2.41 & 0.044 & 0.625 \\
\hline Voeropname, kg/d & 810 & 800 & 13 & 0.618 \\
\hline Groei, g/d & 2.99 & 3.06 & 0.08 & 0.565 \\
\hline Voederconversie & & & \\
\hline
\end{tabular}

\section{Karkaskenmerken ${ }^{2}$}

Karkasgewicht, kg

Vleespercentage, \%

Spierdikte, $\mathrm{mm}$

\begin{tabular}{rrrr}
94.0 & 94.5 & 0.89 & 0.732 \\
57.8 & 57.3 & 0.41 & 0.550 \\
64.4 & 65.3 & 1.32 & 0.675 \\
\hline 16.0 & 16.6 & 0.59 & 0.529 \\
\hline
\end{tabular}

1 Tussen haakjes de groei en voederconversie inclusief de 6 dieren die uit groep 1 werden verwijderd vanwege staartbijten.

2 Per groep ontbraken 3-8 dieren door onvolledige terugkoppeling van de slachtgegevens.

\subsection{Vertering}

In tabel 3 zijn de verteringscoëfficiënten van de voeders weergegeven. Eén waarneming in de startvoerperiode had een afwijkend lage waarde voor de verteerbaarheid van as, Ca en P. Deze is bij de analyse buiten beschouwing gelaten. In tabel 3 zijn de resultaten met en zonder deze waarneming weergegeven. 
De organische stofverteerbaarheid van de vleesvarkensrantsoenen was circa $2 \%$-punten hoger $(P=0,012)$ dan van de startvoerrantsoenen. Dit kan een gevolg zijn van de hogere verteerbaarheid bij oudere varkens zoals beschreven door Noblet and Shi (1993) en/of door verschillen in rantsoensamenstelling. De lagere verteringscoëfficiënt van de anorganische stof in de tweede periode $(P<0,001)$ is een gevolg van het toevoegen van diamol in de periode dat de verteerbaarheid werd bepaald. In de startvoerperiode waren nog geen voeders met diamol beschikbaar. Desondanks kon de verteerbaarheid worden bepaald op basis van het gehalte natuurlijk aanwezige $\mathrm{HCl}$-onoplosbare as in de rantsoenen. De spreiding in verteerbaarheid binnen de behandelingsgroepen leek in de startvoerperiode iets hoger, wellicht ten gevolge van de relatief grotere variatie en analysefout bij een lager diamolgehalte.

De Ca-verteerbaarheid was lager in de tweede periode $(P<0,008)$. Bij de fosforverteerbaarheid was er een interactie tussen periode en proefbehandeling: in de startvoerperiode was de verteerbaarheid hoger in het controlevoer terwijl in de vleesvarkensperiode de verteerbaarheid lager was in het controlerantsoen. In principe mag een hogere verteerbaarheid van $\mathrm{P}$ in het controlevoer verwacht worden omdat het toegevoegd $\mathrm{P}$ uit monocalciumfosfaat een theoretische verteerbaarheid van ca. 83\% heeft (CVB, 2016). Aan de andere kant kan een hoger P-gehalte in het voer resulteren in een afname van de verteerbaarheid wanneer in de behoefte is voorzien. Dit laatste effect zou naar verwachting echter hoger zijn bij de oudere varkens vanwege hun lagere vP-behoefte per EW. Aan de gevonden interactie kunnen daarom geen harde conclusies verbonden worden, temeer daar het weglaten van de afwijkende waarneming een grote invloed op deze resultaten. Het lijkt er op dat het gerealiseerde verschil in VP-gehalte tussen het controlerantsoen en rantsoen met verlaagd vP-gehalte kleiner was dan berekend door kleine verschillen in verteerbaarheid. Daarnaast duiden de resultaten in tabel 3 er op dat voor alle voeders het gerealiseerde vP-gehalte beduidend hoger was dan vooraf was berekend (tabel 1). Dit verschil was het grootst in de vleesvarkensvoeders en werd met name veroorzaakt door een hogere verteerbaarheid dan was ingerekend. De consequenties hiervan worden in paragraaf 3.8 besproken.

Tabel 3 Invloed van een verlaging van het verteerbaar fosfor ( $\mathrm{vP}$ ) gehalte in het voer met 0,4 $\mathrm{g} / \mathrm{kg}$ op de verteringscoëfficiënt (\%) van de rantsoenen in de start- en vleesvarkensperiode, respectievelijk 2 en 11/13 weken na opleggen van biologisch gehouden vleesvarkens. ${ }^{1)}$

\begin{tabular}{|c|c|c|c|c|c|c|c|c|}
\hline \multirow[t]{2}{*}{ Nutriënt } & \multicolumn{2}{|c|}{2 w na opleg } & \multicolumn{2}{|c|}{ 11/ 13 w na opleg } & \multicolumn{4}{|c|}{ P-waarde } \\
\hline & CON & Laag $\mathrm{P}$ & CON & Laag $\mathrm{P}$ & SEM & Periode & Fosfor & $P \times F$ \\
\hline Drogestof & $\begin{array}{c}80,1 \\
(79,6)\end{array}$ & 80,8 & 80,4 & 82,1 & $\begin{array}{c}0,84 \\
(0,72)\end{array}$ & $\begin{array}{c}0,246 \\
(0,136)\end{array}$ & $\begin{array}{c}0,354 \\
(0,219)\end{array}$ & $\begin{array}{c}0,482 \\
(0,735)\end{array}$ \\
\hline Organische stof & $\begin{array}{c}81,6 \\
(81,3)\end{array}$ & 82,3 & 83,7 & 85,1 & $\begin{array}{c}0,87 \\
(0,76)\end{array}$ & $\begin{array}{c}0,012 \\
(0,005)\end{array}$ & $\begin{array}{c}0,422 \\
(0,300)\end{array}$ & $\begin{array}{c}0,595 \\
(0,799)\end{array}$ \\
\hline Anorganische stof & $\begin{array}{c}55,3 \\
(53,3)\end{array}$ & 55,5 & 39,3 & 40,2 & $\begin{array}{c}0,55 \\
(1,03)\end{array}$ & $\begin{array}{c}<0,001 \\
(<0,001)\end{array}$ & $\begin{array}{c}0,441 \\
(0,235)\end{array}$ & $\begin{array}{c}0,493 \\
(0,572)\end{array}$ \\
\hline Calcium & $\begin{array}{c}62,2 \\
(57,1)\end{array}$ & 62,3 & 56,8 & 60,3 & $\begin{array}{c}1,22 \\
(2,03)\end{array}$ & $\begin{array}{c}0,008 \\
(0,689)\end{array}$ & $\begin{array}{c}0,347 \\
(0,054)\end{array}$ & $\begin{array}{c}0,101 \\
(0,767)\end{array}$ \\
\hline Fosfor & $\begin{array}{c}54,8 \\
(51,1)\end{array}$ & 52,7 & 51,0 & 54,9 & $\begin{array}{c}2,26 \\
(2,08)\end{array}$ & $\begin{array}{c}0,493 \\
(0,621)\end{array}$ & $\begin{array}{c}0,802 \\
(0,316)\end{array}$ & $\begin{array}{c}0,035 \\
(0,608)\end{array}$ \\
\hline Verteerbaar $\mathrm{P}, \mathrm{g} / \mathrm{kg}$ & $\begin{array}{c}2,99 \\
(2,84)\end{array}$ & 2,71 & 2,66 & 2,68 & - & - & - & - \\
\hline Verteerbaar $\mathrm{Ca}, \mathrm{g} / \mathrm{kg}$ & $\begin{array}{c}5,25 \\
(4,92)\end{array}$ & 4,99 & 3,28 & 3,18 & - & - & - & - \\
\hline
\end{tabular}

1) Eén waarneming in de startvoerperiode had een afwijkend lage waarde voor de verteerbaarheid van as, Ca en $P$. Deze is bij de analyse buiten beschouwing gelaten. De waarden tussen haakje geven de resultaten inclusief deze afwijkende waarneming.

\subsection{Excretie in de urine}

In tabel 4 is het gehalte aan Ca en $\mathrm{P}$ in urine van varkens in de startvoerperiode ( 2 weken na opleg) en in de vleesvarkensperiode (10 weken na opleg) weergegeven. De resultaten zijn weergegeven ten 
opzichte van creatinine om rekening te houden met eventuele verschillen in urineproductie. De verlaging van het $P$-gehalte in het rantsoen resulteerde in een toename van het Ca-gehalte $(P=0.051)$ in de urine en een niet-significante daling $(\mathrm{P}=0.132)$ van het $\mathrm{P}$-gehalte. Deze verschuiving duidt erop dat er door de verlaging van het $\mathrm{P}$-gehalte in het rantsoen een relatieve overmaat aan geabsorbeerd $\mathrm{Ca}$ ontstond die niet door het dier kon worden benut en daarom uitgescheiden werd met de urine. $\mathrm{Er}$ was daarbij echter nog steeds een substantiële excretie van $\mathrm{P}$ in de urine, wat er op kan duiden dat $\mathrm{P}$ boven de behoefte werd verstrekt. Dit wordt in paragraaf 3.8 verder besproken.

Tabel 4 Invloed van een verlaging van het verteerbaar fosfor (vP) gehalte in het rantsoen met $0,4 \mathrm{~g} / \mathrm{kg}$ op het calcium en fosforgehalte in de urine in de start- en vleesvarkensperiode, respectievelijk 2 en 10 weken na opleggen van biologisch gehouden vleesvarkens.

\begin{tabular}{|c|c|c|c|c|c|c|c|c|}
\hline \multirow[t]{2}{*}{ Nutriënt } & \multicolumn{2}{|c|}{2 w na opleg } & \multicolumn{2}{|c|}{10 w na opleg } & \multicolumn{4}{|c|}{ P-waarde } \\
\hline & CON & Laag- $P$ & CON & Laag-P & SEM & Periode & Fosfor & $\mathrm{P} \times \mathrm{F}$ \\
\hline Creatinine, $\mu \mathrm{mol} / \mathrm{L}$ & 9,8 & 8,8 & 13,9 & 12,0 & 0,41 & $<0,001$ & 0,035 & 0,358 \\
\hline Calcium, $\mathrm{mmol} / \mathrm{L}$ & 3,2 & 6,8 & 2,6 & 6,8 & 0,95 & 0,612 & 0,083 & 0,626 \\
\hline Fosfor, $\mathrm{mmol} / \mathrm{L}$ & 2,4 & 0,53 & 2,9 & 0,32 & 0,80 & 0,745 & 0,160 & 0,456 \\
\hline $\mathrm{Ca} /$ creatinine, $\mathrm{mmol} / \mathrm{L}$ & 0,33 & 0,76 & 0,20 & 0,55 & 0,077 & 0,007 & 0,051 & 0,498 \\
\hline $\mathrm{P} /$ creatinine, $\mathrm{mmol} / \mathrm{L}$ & 0,232 & 0,057 & 0,196 & 0,027 & 0,057 & 0,421 & 0,132 & 0,942 \\
\hline
\end{tabular}

\subsection{Bloedspiegels}

In tabel 5 is het gehalte aan Ca en anorganisch $\mathrm{P}$ in bloed van varkens in de startperiode ( 3 weken na opleggen) en in de vleesvarkensperiode (11 weken na opleggen) weergegeven. De resultaten laten zien dat de verlaging van het P-gehalte geen significant effect had op het Ca- en P-gehalte in het bloed. Voor $\mathrm{P}$ was er een effect van periode, waarbij het $\mathrm{P}$-gehalte hoger was bij de oudere varkens. Dit kan erop duiden dat voor de oudere varkens het P-gehalte in het rantsoen ten opzichte van de behoefte ruimer was dan voor de varkens in de startvoerfase. Resultaten van Bikker et al. (2013b) lieten zien dat verhoging van het P-gehalte in het rantsoen resulteert in een curvilineaire toename van het anorganisch P-gehalte in het bloed. De gehalten voor Ca en $\mathrm{P}$ bevinden zich op een normaal niveau voor groeiende varkens en duiden niet op een tekort aan Ca of P (Bikker et al., 2013b).

Tabel 5 Invloed van een verlaging van het verteerbaar fosfor (vP) gehalte in het rantsoen met $0,4 \mathrm{~g} / \mathrm{kg}$ op het calcium en fosforgehalte in bloedplasma in de start- en vleesvarkensperiode, respectievelijk 3 en 11 weken na opleggen van biologisch gehouden vleesvarkens.

\begin{tabular}{|c|c|c|c|c|c|c|c|c|}
\hline \multirow[t]{2}{*}{ Nutriënt } & \multicolumn{2}{|c|}{2 w na opleg } & \multicolumn{2}{|c|}{10 w na opleg } & \multicolumn{4}{|c|}{ P-waarde } \\
\hline & CON & Laag-P & CON & Laag-P & SEM & Periode & Fosfor & $\mathrm{P} \times \mathrm{F}$ \\
\hline Calcium, $\mathrm{mmol} / \mathrm{L}$ & 2.57 & 2.67 & 2.68 & 2.67 & 0.050 & 0.270 & 0.347 & 0.291 \\
\hline Fosfor, $\mathrm{mmol} / \mathrm{L}$ & 2.95 & 2.78 & 3.25 & 3.21 & 0.142 & 0.002 & 0.613 & 0.550 \\
\hline
\end{tabular}

\subsection{Botkenmerken}

In tabel 6 zijn de resultaten weergegeven van het gewicht en de samenstelling van de metacarpus 3 en metacarpus 4 in de voorpoot van het varken. De verlaging in P-gehalte van het rantsoen had geen significant effect op het vers gewicht, het asgewicht en het asgehalte in de vetvrije drogestof van deze botjes. Numeriek was het asgewicht en het asgehalte iets lager bij het rantsoen met verlaagd Pgehalte.

Dit komt overeen met de verwachting omdat een toename van het Ca en P-gehalte van het rantsoen resulteert in een toename van de botmineralisatie (Bikker et al., 2013b). Deze toename werd ook gevonden wanneer reeds in de behoefte voor maximale groei was voorzien. 
Tabel 6 Invloed van een verlaging van het verteerbaar fosfor (vP) gehalte in het rantsoen met $0,4 \mathrm{~g} / \mathrm{kg}$ op gewicht en anorganische stof van de metacarpus 3 en 4 van biologisch gehouden vleesvarkens na slachten bij een levend gewicht van ca. $120 \mathrm{~kg}$.

\begin{tabular}{lcccc} 
Kenmerk & Controle & Laag P & SEM & P-waarde \\
Karkasgewicht, kg & 95.4 & 94.4 & 0.88 & 0.512 \\
\hline M3, gewicht vers, g & 31.9 & 30.7 & 0.71 & 0.337 \\
\hline M4, gewicht vers, g & 29.7 & 29.1 & 0.47 & 0.484 \\
\hline M3 + 4, gewicht vers, g & 61.6 & 59.8 & 1.15 & 0.378 \\
\hline M3, gewicht as, g & 8.80 & 8.12 & 0.23 & 0.170 \\
\hline M4, gewicht as, g & 8.35 & 7.81 & 0.15 & 0.128 \\
\hline M3 + 4, gewicht as, g & 17.2 & 15.9 & 0.38 & 0.147 \\
\hline M4, as in VVDS, g/kg & 519 & 506 & 4.9 & 0.180 \\
\hline
\end{tabular}

\subsection{Algemene discussie}

Dit onderzoek is uitgevoerd om na te gaan of het in de praktijk mogelijk is het vP-gehalte in het rantsoen van biologisch gehouden groeiende varkens te verlagen zonder dat dit ten koste gaat van de gezondheid en groeiprestaties van de dieren. Onze hypothese was dat dit mogelijk zou zijn omdat: i) de normen voor groeiende varkens gebaseerd zijn op een ruime botmineralisatie (vastlegging van Ca en $\mathrm{P}$ in bot) (J ongbloed et al., 2003); ii) biologisch gehouden dieren veelal een hogere voederconversie hebben dan conventioneel gehouden dieren, waardoor per kg groei meer mineralen beschikbaar zijn voor botaanzet; iii) de grotere bewegingsvrijheid voor biologische varkens een gunstig effect op beenwerk en botkwaliteit kan hebben. Zowel in het startrantsoen als in het vleesvarkensrantsoen werd het berekende vP-gehalte met $0,4 \mathrm{~g} / \mathrm{kg}$ (respectievelijk 15 en 20\%) verlaagd ten opzichte van het controlevoer. De rantsoenen bestonden uit een granenmengsel en een aanvullend start- en vleesvarkensvoer. Het contrast werd aangelegd door aan het granenmengsel wel (controle) of geen (verlaagd vP-gehalte) monocalciumfosfaat toe te voegen. De geanalyseerde nutriëntgehalten (tabel 1) duiden erop dat dit correct is uitgevoerd. Het gemiddeld gerealiseerde vPgehalte in het controlevoer op basis van analyse van voer en mest was echter aanzienlijk hoger dan vooraf berekend: ca. $15 \%$ in startvoer en $40 \%$ in vleesvarkensvoer. Dit werd voornamelijk veroorzaakt door een aanzienlijk hogere P-vertering van 50-55\% dan waarmee bij de mengvoerbereiding werd gerekend, met name in het vleesvarkensvoer. Dit betekent dat de Pverteerbaarheid van (een aantal) voeringrediënten hoger was dan waarmee werd gerekend in de voermatrix. Wanneer kennis over de (variatie in) verteerbaarheid van $\mathrm{P}$ in de (biologische) grondstoffen beter bekend is kan hiervan gebruik gemaakt worden om het P-gehalte van de voeders te verlagen en de $P$ benutting te verhogen. Hierbij kan de aanwezigheid en waardering van intrinsiek fytase in graan en graanproducten een belangrijke rol spelen. Intrinsiek fytase kan een belangrijke bijdrage leveren aan de verteerbaarheid van $\mathrm{P}$ in biologische voeders zonder microbieel fytase, maar dit effect wordt veelal slechts in beperkte mate ingerekend omdat het gehalte aan intrinsiek fytase, de effectiviteit en de stabiliteit tijdens pelleteren niet precies bekend zijn. Intrinsiek fytase is minder thermostabiel dan microbieel fytase, waardoor een deel hiervan tijdens het pelletteerproces wordt vernietigd. Mede door gebruik van een niet gepelleteerd granenmengsel bleek er in deze proef een aanzienlijk fytasegehalte van ca. $250 \mathrm{FTU} / \mathrm{kg}$ in de rantsoenen aanwezig te zijn. Dit heeft niet alleen een gunstig effect op de P-vertering van de betreffende grondstoffen, maar kan ook bijdragen aan fytaatafbraak en een hogere vertering van $\mathrm{P}$ uit andere grondstoffen in het rantsoen (Esmaeilipour, 2013). Concluderend kan het beter inschatten van het vP-gehalte van de voeders, waarbij rekening gehouden wordt met de eventuele aanwezigheid van intrinsiek fytase, bijdragen aan het gerichter voeren van de varkens en een efficiëntere P-benutting. Door gebruik van niet of slechts mild gepelletteerde granen in het rantsoen kan het intrinsiek fytasegehalte van het rantsoen en daarmee de verteerbaarheid en benutting van $P$ verhoogd worden.

De voeders met verlaagd vP-gehalte hadden een vP-gehalte op of ruim boven de norm voor regulier gehouden varkens. De verlaging van het vP-gehalte had geen significante invloed op de groeiprestaties en de Ca en P-spiegels in het bloed, en deze lagen op een normaal niveau voor groeiende varkens. De botmineralisatie was numeriek (niet significant) lager bij het lagere vP-gehalte. 
Dit komt overeen met eerdere resultaten van Bikker et al. (2013b) waarin het verstrekken van extra VP (ruim) boven de adviesnorm (J ongbloed et al., 2003) geen invloed had op de bloedwaarden en groeiprestaties, maar wel resulteerde in een hoger botasgewicht. Omgekeerd resulteert een verlaging van het vP-gehalte dus in een lager botasgewicht. Wanneer de maximale groei is bereikt kan extra vP nog steeds worden gebruikt voor een hogere botmineralisatie en resulteert een lager vP-gehalte in een lagere botmineralisatie. De hier gevonden daling in botmineralisatie bij de vP-verlaging komt overeen met de toename in Ca-gehalte in de urine. Bij de controlebehandeling zijn de Ca en Pgehalten in de urine ongeveer even hoog. Bij de varkens met een verlaagd vP-gehalte is het $\mathrm{Ca}$ gehalte in de urine 10-20x zo hoog als het P-gehalte (in mmol). Deze toename in $\mathrm{Ca} / \mathrm{P}$ verhouding in de urine bij een verlaging van het gehalte aan monocalciumfosfaat in het voer komt overeen met resultaten van Stein et al. (2008). Monocalciumfosfaat heeft een hoger gehalte aan (verteerbaar) $\mathrm{P}$ dan $\mathrm{Ca}$. Bij een verlaging van het aandeel monocalciumfosfaat in het rantsoen daalt hierdoor het (verteerbaar) P-gehalte sterker dan het Ca-gehalte, de botmineralisatie daalt en er ontstaat een relatief overschot aan $\mathrm{Ca}$. Omgekeerd, bij het verstrekken van extra monocalciumfosfaat (controle) daalde de excretie van $\mathrm{Ca}$ in de urine, wat erop duidt dat er meer Ca en P werd vastgelegd door botmineralisatie.

Concluderend kan als gevolg van het onbedoeld hoge vP-gehalte in de rantsoenen op basis van de hier beschreven proef geen uitspraak gedaan worden over de consequenties van een verlaging van het vPgehalte tot onder de norm voor regulier gehouden varkens. Bij het gerealiseerde vP-gehalte in het controlerantsoen kan het P-gehalte verlaagd worden zonder negatieve invloed op groeiprestaties en gezondheid van de dieren. De botmineralisatie zal hierdoor naar verwachting iets dalen zonder negatieve consequenties voor de gezondheid van de dieren. 


\section{Conclusies}

Deze praktijkstudie is uitgevoerd om na te gaan of het verteerbaar fosfor (VP) gehalte in het rantsoen voor biologisch gehouden groeiende varkens ten opzichte van de van de gangbare norm verlaagd kan worden zonder dat dit ten koste gaat van de groeiprestaties en de diergezondheid. Uit de resultaten concluderen we:

- de verlaging van het berekend vP-gehalte met $0,4 \mathrm{~g} / \mathrm{kg}$ ( $15 \%$ in startvoer, $20 \%$ in vleesvarkensvoer) had geen invloed op de groeiprestaties en gezondheid van de varkens. Een verlaging ten opzichte van het in deze proef gebruikte controlerantsoen kan dus zonder problemen in de praktijk worden toegepast;

- de gerealiseerde vP-gehalten, gebaseerd op analyses van voer en mest (feces), in het controlerantsoen en het rantsoen met verlaagd vP-gehalte lagen echter beide aanmerkelijk hoger dan vooraf was berekend op basis van tabelwaarden voor de verteerbaarheid van P. Als gevolg hiervan kan geen uitspraak gedaan worden over de consequenties voor groeiprestaties en gezondheid van een verlaging van het vP-gehalte tot 15 à $20 \%$ onder de norm voor reguliere varkens;

- $\quad$ meer inzicht en een betere inschatting van het vP-gehalte van de voeders, inclusief het effect van aanwezig intrinsiek fytase kan de kans op over- of onder dosering van vP verminderen en bijdragen aan het gerichter op de vP-norm voeren van de varkens en een efficiëntere P-benutting. 


\section{Literatuur}

Bikker, P. and M.C. Blok. 2017. Phosphorus and calcium requirements of growing pigs and sows. Wageningen Livestock Research, CVB documentation report 59.

Bikker, P., J. van Harn, C. Groenestein, J. de Wit, C. van Bruggen, en H. Luesink. 2013a. Stikstof- en fosforexcretie van varkens, pluimvee en rundvee in biologische en gangbare houderijsystemen. Wageningen: Wettelijke Onderzoekstaken Natuur \& Milieu WOt-werkdocument 347.

Bikker, P., R.A. Dekker, J.Th.M. van Diepen, M.M. van Krimpen, A.W. Jongbloed, en S. Millet. 2013 b. Behoefte en vastlegging van fosfor bij vleesvarkens. Wageningen UR Livestock Research, rapport 723.

CVB, 2012. Tabellenboek Veevoeding; voedernormen landbouwhuisdieren en voederwaarde veevoeders. CVB-reeks nr. 50. Productschap Diervoeder Den Haag.

CVB. 2016. Veevoedertabel. Chemische samenstellingen en nutritionele waarden van voedermiddelen. Federatie Nederlandse Diervoederketen, Rijswijk, en Wageningen Livestock Research, Wageningen, Nederland.

Esmaeilipour, O., M.M. van Krimpen, A.W. Jongbloed, L.H. de Jonge, and P. Bikker. 2013. The effects of temperature, moisture, duration of incubation time, calcium level, and soaking with water or citric acid on in vitro phytate degradation in a wheat-barley-rye-soybean meal-based diet. Anim. Feed Sci. and Technol. 183: 168-174.

Früh, B, B. Schlatter, A. I sensee, V. Maurer and H. Willer. 2015. Report on organic protein availability and demand in Europe. Research Institute of Organic Agriculture (FiBL), Frick, Switzerland.

J ongbloed, A.W., J.Th.M. van Diepen en P.A. Kemme. 2003. Fosfornormen voor varkens: herziening 2003. CVB-documentatierapport nr. 30.

Marchant, J., and D. Broom. 1996. Effects of dry sow housing conditions on muscle weight and bone strength. Anim. Sci. 62:105-113.

Nauta, W. en S. Staps. 2011. Kansen voor pluimveemest in de gehele biologische productieketen. Louis Bolk instituut, Rapport LbP014.

Noblet, J. and X.S. Shi. 1994. Effect of body weight on digestive utilization of energy and nutrients of ingredients and diets in pigs. Livest. Prod. Sci. 37, 323-338.

Peet-Schwering, C.M.C. van der, G.P. Binnendijk en A.W. Jongbloed. 2009. Minder eiwit in biologisch vleesvarkensvoer in de winter. Wageningen UR Livestock Research, rapport 266, 21 p.

Prins, U en F. de Buisonjé, 2014. Bio-mest op bio-grond. Mestkwaliteit in relatie tot toepassing in de kringloop. Notitie Louis Bolk Instituut, Wageningen UR Livestock Research en Biohuis.

Stein, H.H., C.T. Kadzere, S.W. Kim, and P.S. Miller. 2008. Influence of dietary phosphorus concentration on the digestibility of phosphorus in monocalcium phosphate by growing pigs. J. Anim. Sci. 86: 1861-1867. 


\section{Bijlage 1 Gehanteerde voerschema's}

\begin{tabular}{|c|c|c|c|c|c|c|c|c|c|c|}
\hline & & & & \multicolumn{3}{|c|}{ Te gebruiken mengsels } & \multirow[b]{2}{*}{ afmest } & \multirow{2}{*}{\multicolumn{2}{|c|}{ Laag P mengsel|Hoog P mengsel }} & \multirow[b]{2}{*}{ totaal } \\
\hline & & & & \begin{tabular}{|l|} 
mengsel \\
\end{tabular} & & startvoer & & & & \\
\hline & & & & 26 & & 68,5 & & & 31,5 & 100 \\
\hline & & & & 27 & & 41,5 & 27 & & 31,5 & 100 \\
\hline & & & & 28 & & 28,5 & 40 & & 31,5 & 100 \\
\hline Hoog P & & CURVE 5 & & 29 & & & 68,5 & & 31,5 & 100 \\
\hline \multirow{2}{*}{\multicolumn{11}{|c|}{ Voerschema borgen en gelten }} \\
\hline & & & & & & & & & & \\
\hline & & & & & Percentage & joersoort & & Laag P groep & Hoog P groep & \\
\hline \multirow[t]{2}{*}{ dag } & LG & EW/dag & stijging & mengsel & biggenvoer & startvoer & afmest & voormengsel & Voormengsel & totaal \\
\hline & & & & & & & & Reudink & eigen & \\
\hline 1 & 23 & 0,95 & & 26 & & 68,5 & & & 31,5 & 100 \\
\hline 7 & 25 & 1,10 & 0,15 & 26 & & 68,5 & & & 31,5 & 100 \\
\hline 14 & 30 & 1,30 & 0,20 & 26 & & 68,5 & & & 31,5 & 100 \\
\hline 21 & 35 & 1,50 & 0,20 & 26 & & 68,5 & & & 31,5 & 100 \\
\hline 28 & 40 & 1,70 & 0,20 & 26 & & 68,5 & & & 31,5 & 100 \\
\hline 35 & 45 & 1,90 & 0,20 & 26 & & 68,5 & & & 31,5 & 100 \\
\hline 42 & 50 & 2,10 & 0,20 & 27 & & 41,5 & 27 & & 31,5 & 100 \\
\hline 49 & 56 & 2,30 & 0,20 & 28 & & 28,5 & 40 & & 31,5 & 100 \\
\hline 56 & 63 & 2,50 & 0,20 & 29 & & & 68,5 & & 31,5 & 100 \\
\hline 63 & 68 & 2,70 & 0,20 & 29 & & & 68,5 & & 31,5 & 100 \\
\hline 70 & 72 & 2,80 & 0,10 & 29 & & & 68,5 & & 31,5 & 100 \\
\hline 77 & 80 & 2,86 & 0,06 & 29 & & & 68,5 & & 31,5 & 100 \\
\hline 84 & 88 & 2,86 & 0,00 & 29 & & & 68,5 & & 31,5 & 100 \\
\hline 91 & 95 & 2,86 & 0,00 & 29 & & & 68,5 & & 31,5 & 100 \\
\hline 98 & 100 & 2,86 & 0,00 & 29 & & & 68,5 & & 31,5 & 100 \\
\hline 105 & 106 & 2,86 & 0,00 & 29 & & & 68,5 & & 31,5 & 100 \\
\hline 112 & 112 & 2,86 & 0,00 & 29 & & & 68,5 & & 31,5 & 100 \\
\hline 119 & 117 & 2,86 & 0,00 & 29 & & & 68,5 & & 31,5 & 100 \\
\hline
\end{tabular}

\begin{tabular}{|c|c|c|c|c|c|c|c|c|c|c|}
\hline & & & & \multicolumn{3}{|c|}{ Te gebruiken mengsels } & & & & \multirow[b]{2}{*}{ totaal } \\
\hline & & & & mengsel & & startvoer & afmest & Laag P mengsel & Hoog P mengsel| & \\
\hline & & & & 21 & & 67 & & 33 & & 100 \\
\hline & & & & 22 & & 40 & 27 & 33 & & 100 \\
\hline \multirow[t]{2}{*}{ Laag P } & & CURVE 4 & & 23 & & 27 & 40 & 33 & & 100 \\
\hline & & & & 24 & & & 67 & 33 & & 100 \\
\hline \multicolumn{11}{|c|}{ Voerschema borgen en gelten } \\
\hline & & & & & & & & & & \\
\hline & & & & & \multicolumn{2}{|c|}{ Percentage voersoort } & & Laag P groep & Hoog P groep & \\
\hline \multirow[t]{2}{*}{ dag } & LG & EW/dag & stijging & mengsel & biggenvoer & startvoer & afmest & voormengsel & Voormengsel & \multirow[t]{2}{*}{ totaal } \\
\hline & & & & & & & & Reudink & eigen & \\
\hline 1 & 23 & 0,95 & & 21 & & 67 & & 33 & & 100 \\
\hline 7 & 25 & 1,10 & 0,15 & 21 & & 67 & & 33 & & 100 \\
\hline 14 & 30 & 1,30 & 0,20 & 21 & & 67 & & 33 & & 100 \\
\hline 21 & 35 & 1,50 & 0,20 & 21 & & 67 & & 33 & & 100 \\
\hline 28 & 40 & 1,70 & 0,20 & 21 & & 67 & & 33 & & 100 \\
\hline 35 & 45 & 1,90 & 0,20 & 21 & & 67 & & 33 & & 100 \\
\hline 42 & 50 & 2,10 & 0,20 & 22 & & 40 & 27 & 33 & & 100 \\
\hline 49 & 56 & 2,30 & 0,20 & 23 & & 27 & 40 & 33 & & 100 \\
\hline 56 & 63 & 2,50 & 0,20 & 24 & & & 67 & 33 & & 100 \\
\hline 63 & 68 & 2,70 & 0,20 & 24 & & & 67 & 33 & & 100 \\
\hline 70 & 72 & 2,80 & 0,10 & 24 & & & 67 & 33 & & 100 \\
\hline 77 & 80 & 2,86 & 0,06 & 24 & & & 67 & 33 & & 100 \\
\hline 84 & 88 & 2,86 & 0,00 & 24 & & & 67 & 33 & & 100 \\
\hline 91 & 95 & 2,86 & 0,00 & 24 & & & 67 & 33 & & 100 \\
\hline 98 & 100 & 2,86 & 0,00 & 24 & & & 67 & 33 & & 100 \\
\hline 105 & 106 & 2,86 & 0,00 & 24 & & & 67 & 33 & & 100 \\
\hline 112 & 112 & 2,86 & 0,00 & 24 & & & 67 & 33 & & 100 \\
\hline 119 & 117 & 2,86 & 0,00 & 24 & & & 67 & 33 & & 100 \\
\hline & & & & & & & & & & \\
\hline
\end{tabular}




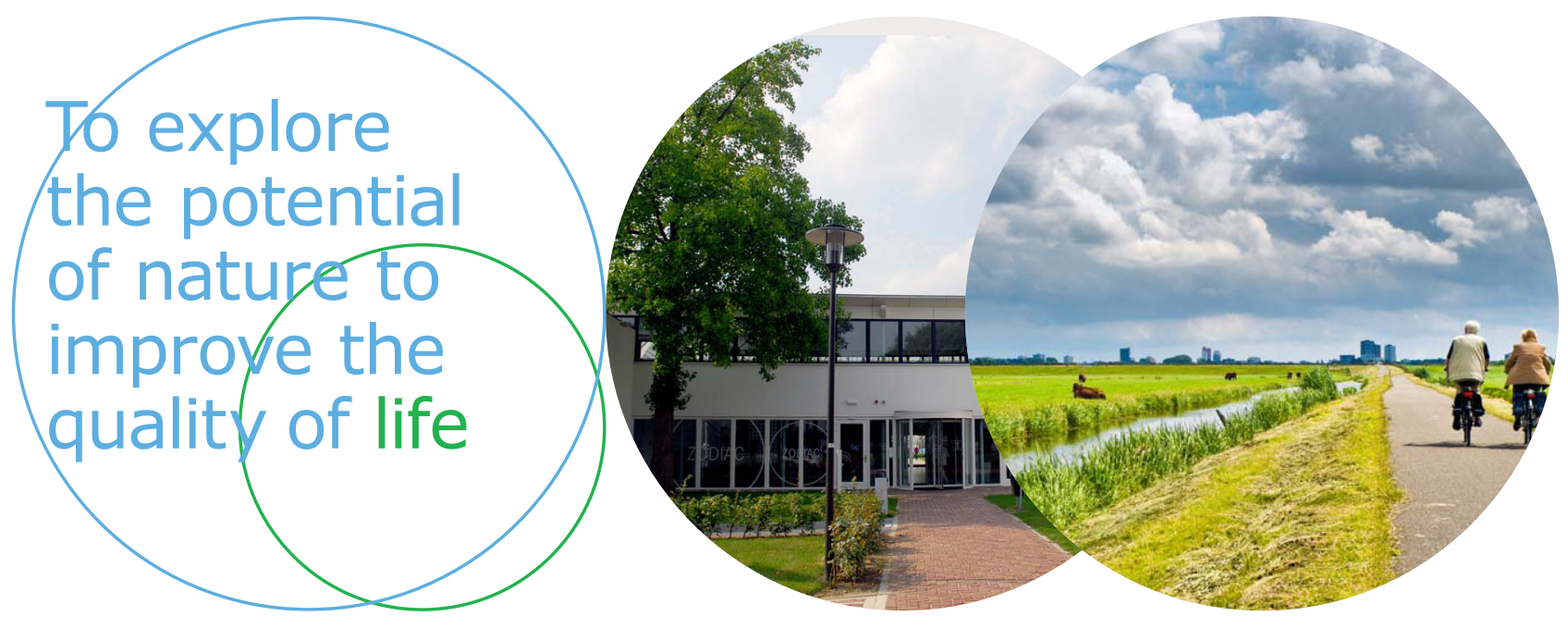

Wageningen Livestock Research Postbus 338

Wageningen Livestock Research ontwikkelt kennis voor een zorgvuldige en $6700 \mathrm{AH}$ Wageningen

T 0317483953

renderende veehouderij, vertaalt deze naar praktijkgerichte oplossingen en innovaties, en zorgt voor doorstroming van deze kennis. Onze wetenschappelijke E info.livestockresearch@wur.nl www.wur.nl/ livestock-research kennis op het gebied van veehouderijsystemen en van voeding, genetica, welzijn en milieu-impact van landbouwhuisdieren integreren we, samen met onze klanten, tot veehouderijconcepten voor de $21 \mathrm{e}$ eeuw.

De missie van Wageningen University \& Research is 'To explore the potential of nature to improve the quality of life'. Binnen Wageningen University \& Research bundelen 9 gespecialiseerde onderzoeksinstituten van Stichting Wageningen Research en Wageningen University hun krachten om bij te dragen aan de oplossing van belangrijke vragen in het domein van gezonde voeding en leefomgeving. Met ongeveer 30 vestigingen, 6.500 medewerkers en 10.000 studenten behoort Wageningen University \& Research wereldwijd tot de aansprekende kennisinstellingen binnen haar domein. De integrale benadering van de vraagstukken en de samenwerking tussen verschillende disciplines vormen het hart van de unieke Wageningen aanpak. 